\title{
Description of the mature nymph of Leuctra andalusiaca Aubert, 1962 (Plecoptera)
}

\section{A. Sanchez-Ortegal \\ J. Alba-Tercedor ${ }^{1}$}

The mature nymph of Leuctra andalusiaca is described and illustrated.

Description du dernier stade larvaire de Letuctra andalusiaca Aubert, 1962.

\section{Introduction}

Aubert (1962) described Leuctra andalusiaca from adults collected in the South of Spain and the types are from the Sierra Nevada.

During an annual series of collections in rivers and streams from the Sierra Nevada, we obtained adults of Leuctra andalusiaca Aub. and after rearing the nymphs in the laboratory it was possible to correlate nymphs and adults.

\section{Material}

Rio Aguas Blancas, 1350 m, U.T.M. : 30 S. VG. 689210 , 26.11.1982, 5 nymphs; ibidem, 1140 m, U.T.M. : $30 \mathrm{~S}$. VG. 649 206, 8.IIl.1982, 2 nymphs ; Rio Chico, 800 m. U.T.M. : 30 S. VF. 632 872, 24.II.1982, 7 nymphs ; ibidem, II.II.1983, 5 nymphs.

\section{Description}

Body length: $\circ 7,22-8,64 \mathrm{~mm}(\overline{\mathrm{x}}=7,84)$; ㅇ $7,32-9,96 \mathrm{~mm}(\mathrm{x}=8,78)$.

General colour olive brown or brown-reddish ; antennae, legs and cerci yellowish ; head with a pattern as shown in figure 1 , with two clear zones behind the antennae; ocelli often defined as light dots, sometimes reddish ; six semilunar dots on the frons ; a characteristic pattern resembling the num. ber "five " (generally not so well defined as in Fig. 1) on the pronotum ; fore third of abdominal tergites sometimes with a line of six little dots.

1. Departamento de Zoologia, Facultad de Ciencias, Universidad de Granada, España.

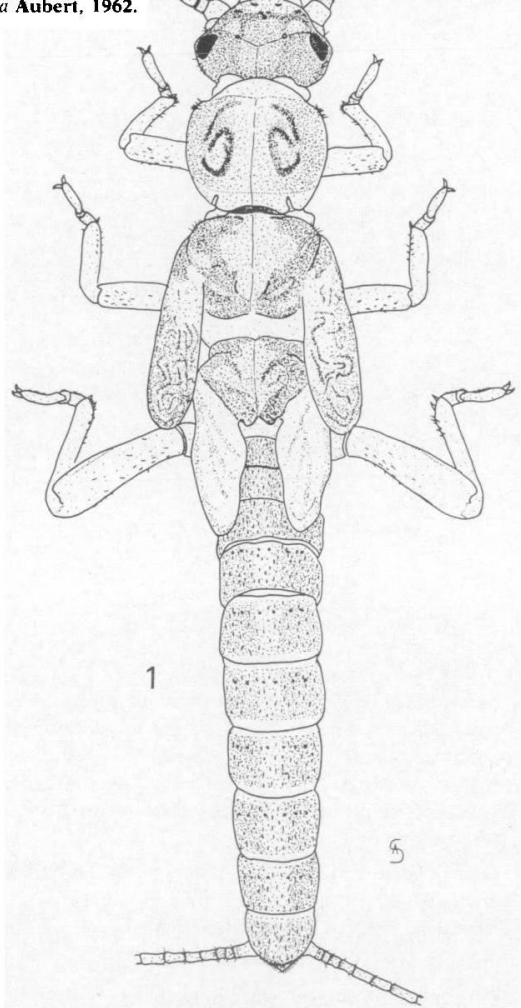

Fig. 1. Leuctra andalusiaca Aubert, mature nymph, dorsal. 

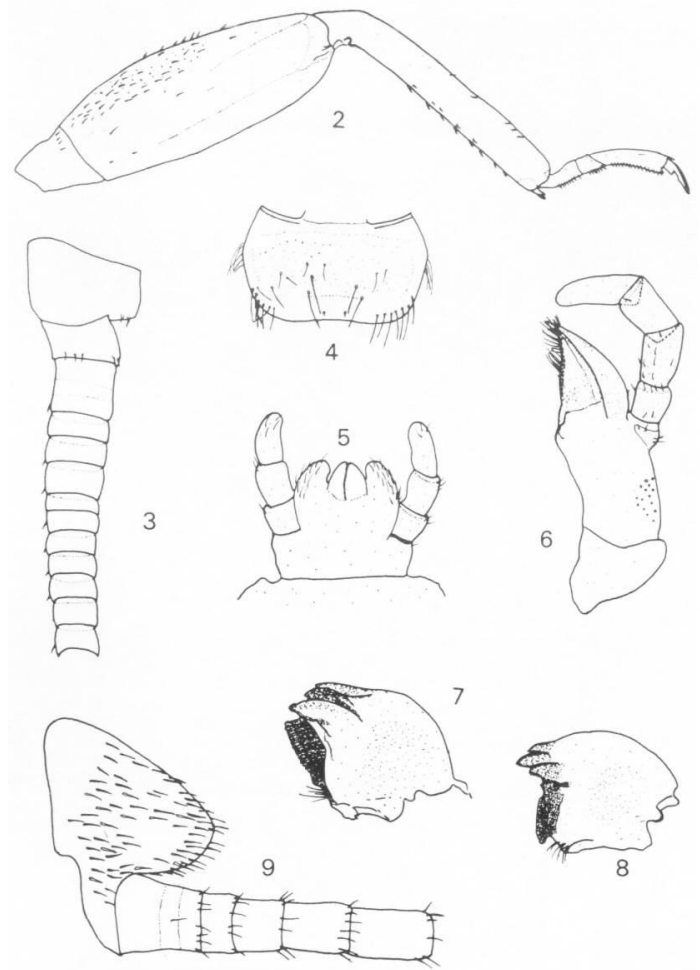

Fig. 2-9. Leuctra andalusiaca Aubert, mature nymph ; 2, hind leg. dorsal ; 3 , first segments of the antenna ; 4. labrum : 5, labium ; 6, maxilla; 7 , left mandibule ; 8 , right mandibule : 9, paraproct and first segments of the cercus.
Antennae (Fig. 3) as long as the head and thorax, without long setae and with only a few small spines on the distal part of the lst and 2nd segments ; on the following segments, only one or two spines and a few small setae. Preflagellum (after Aubert 1951) with 4-5 segments.

Head including the eyes, as large as the pronotum, with 1-2 bristles at the base of each antenna and a few bristles behind the eyes.

Mouth parts as shown in figures 4 to 8 .

Pigmented zone of the pronotum rectangular; lateral margins moderately convex ; corners roun- ded, a few short bristles in the fore corners of both pronotum and mesonotum. Mesonotal prolongations between the wing-pads rounded.

Femur (Fig. 2) with very short pointed spines which are approximately from $1 / 10$ to $1 / 13$ as long as the width of femur. Tibia without long setae but with spines similar to those on the femur. Tarsal segments with fines spines on their inner margins. Surface of legs covered with short and very fine hairs.

Abdominal tergites twice as wide as long, without long setae but densely covered with short pointed bristles wich are approximately $1 / 15$ to $1 / 16$ as long 
as the length of the corresponding pigmented zone of the tergum. Hind margin of the last abdominal tergite pointed.

Cerci as long as the abdomen, with the 2 nd segment shorter than wide (ratio lenght/width, $14: 16$ ) ; 3 rd segment as long as wide (ratio length/width, 21 : 23) ; 4 th, 5 th and 6 th segment longer than wide, with a ratio length/width, $28: 23,33: 21$ and $39: 22$ res. pectively ; segments of cerci with a crown of short bristles (see Fig. 9).

Literature clted

Aubert (J.). 1951. - Plécoptères helvétiques: description de la $\mathrm{T}$. ves nouvelles. Mirt. schueiz. ent. Ges., $24: 279.298$.

Aubert (J.). 1962. - Quelques Leuctra nouvelles pour l'Europe (Plecoptères : Leuctridae) Mitt. schueiz ent. Ges, 35 : 155-169. 